\title{
Rational Use of Energy Raw Materials in the Context of Sustainable Development in the Slovak Republic
}

\author{
Štefan Kuzevič ${ }^{1, *}$, Marcela Bindzárová Gergel'ová ${ }^{2}$, and Žofia Kuzevičová ${ }^{2}$ \\ ${ }^{1}$ Institute of Earth Resources, Faculty of Mining, Ecology, Process Control and Geotechnology, The \\ Technical University of Košice, Letná 9, 04001 Košice, Slovakia \\ ${ }^{2}$ Institute of Geodesy, Cartography and Geographical Information Systems, Faculty of Mining, \\ Ecology, Process Control, and Geotechnology, The Technical University of Košice, Letná 9, 04001 \\ Košice, Slovakia
}

\begin{abstract}
The concept of sustainable development is an important topic in the global concept of the world. It is understood as the unification of social, economic, environmental and institutional development of society. A complicated complex of relationships is formed. The contribution is devoted to selected indicators monitored in Slovakia in the framework of sustainability dealing with the issue of connection and evaluation of environmental protection and exploitation and use of energy raw materials. An important factor is also the reduction of energy consumption, given the decreasing reserves of energy raw materials in Slovakia.
\end{abstract}

\section{Introduction}

The issue of environmental quality and the assessment of environmental indicators is currently highly topical. Every person is entitled to live in an environment that meets the requirements and standards of healthy development and quality of life. To achieve a healthy environment, it is essential to ensure sustainable transport, rational use of natural resources, ensuring sustainable development, and preserving basic natural processes. Every person and society should try to raise the quality of life without increasing the degradation of nature and the environment in which we are.

The basic strategic documents related to the energy sector, energy security and achieving the objectives of sustainable development include the Manifesto of the Government [1], Update raw materials policy [2] and Energy policy [3]. The updated raw material policy sets long-term goals and tools for the effective use and protection of raw material resources while respecting the principles of sustainable development of society and environmental protection. The State should, in its role, ensure the creation of a relatively stable environment for the development of mining and the use of domestic raw materials in order to reduce their dependence on imports, the protection of mineral resources and the use of secondary raw materials, including mining and technological waste and, in particular,

\footnotetext{
* Corresponding author: stefan.kuzevic@tuke.sk
} 
environmental protection. Energy security is an integral part of the country's strategic security. One option is to replace traditional fuels with renewable energy [4].

Long-term priorities (integrated objectives) of sustainable development of Slovakia, which are identified in the National Strategy of Sustainable Development [5] include high quality of environment, protection and rational use of natural resources - effective protection of the environment, careful use of natural resources, elimination of environmental burdens and environmental damage, limiting economic development in accordance with natural conditions and potentials, achieving and maintaining a quality environment with an emphasis on vulnerable areas.

In the context of the rational use of raw materials sources - the wealth of the state, it is also necessary to take into account the impact of mining on the environment and humans [6].

Sustainable development strategic objectives, which are needed in the direction of achieving long-term priority in relation to the environment, are [7]:

- To improve the health status of the population and health care systems due, improvement lifestyle,

- Development an integrated model of agriculture,

- The restructuring and modernising of the banking sector,

- To reduce the energy and raw materials intensity and increasing efficiency of the Slovakia economy,

- Reducing the use of non-renewable natural resources in the rational utilisation of renewable resources,

- To reduce the environmental burden of the environment,

- To mitigation of the climate change impacts, to mitigation the ozone layer damage and natural disasters,

- Enhancement of the environment quality in regions.

\section{Materials and Methods}

Within the framework of the need to monitor and evaluate the fulfilment of the principles of sustainable development and the achievement of objectives in the Slovak Republic, indicators were selected which include all pillars of the sustainable development. (Fig. 1)

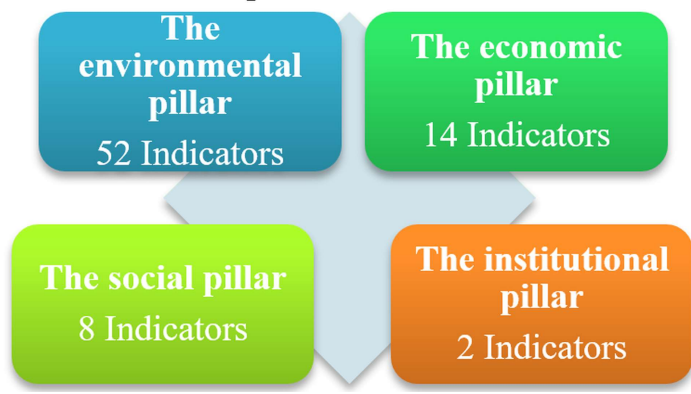

Fig. 1. The pillars of sustainable development.

In the framework of the evaluation of individual strategies, concepts, programs, and activities related to sustainable development based on 16 principles (for human activity management) and 40 criteria (for the application of principles), the environmental section Ecological principle:

- Conservation of biodiversity, vitality and ecosystem resilience,

- Optimization of the spatial arrangement and functional land-use and ensuring its land-use system of ecological stability, 
- Preserving and promoting the life ensure systems,

- Preservation of high quality of components of the environment - minimization of negative impacts on the environment,

- Minimizing the use of non-renewable resources and prioritizing the use of renewable resources but within their reproductive capacity.

Within the individual indicators, it is necessary to collect a large amount of data, which is subsequently processed, analysed and evaluated. To manage this type of data, it is useful to use the geographic information systems and the tools they offer us. Some indicators are currently being processed in the GIS environment and presented to the public either in the form of a map or a map server. An important role is also played by the quality of the data, which then enters the evaluation process and also becomes the basis for assessing the quality of life of the population [8]. The main indicators of EU Sustainable Development are shown in Figure 2.

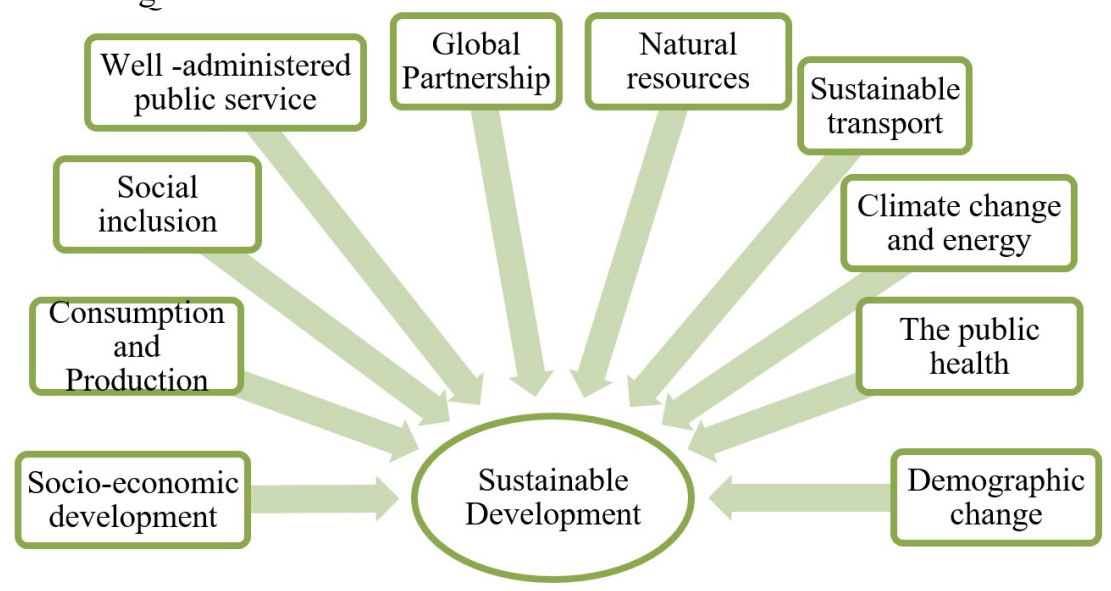

Fig. 2. The indicators of Sustainable Development.

Within the framework of the need to monitor and evaluate the fulfilment of the principles of sustainable development and the achievement of objectives in the Slovak Republic, indicators were selected that include all pillars of sustainable development. Figure 3 shows indicators within the economic pillar.

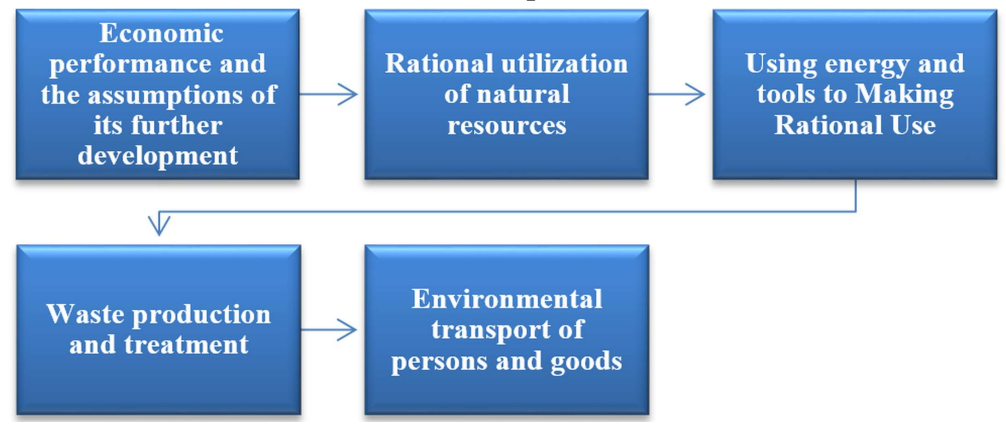

Fig. 3. The issue of sustainable development within the economic pillar.

One of the fundamental priorities of the Energy Policy of the Slovak Republic is to increase the share of renewable energy sources in electricity and heat production in order to create adequate additional resources needed to cover domestic demand $[2,9,10]$. Rational management of domestic renewable energy sources is in line with the principles of 
sustainable development, making it one of the pillars of healthy economic development of society.

\section{Results and Discussion}

Most of the data is currently available in digital form through map servers. In addition to the standard web browser data viewer, the vast majority of map servers also offer other services such as WMS.

In Slovakia, we have a lot of data providers through map servers to the public. Most of the data related to the environment and under the responsibility of the Ministry of the Environment. In compliance with the INSPIRE Directive and its transposition of Act No. 3/2010 Coll. on National Infrastructure for Spatial Information (NIPI), a National Geoportal (NG) was established to provide access to spatial data and spatial data services of NIPIs and obliged entities through network services [11]

Information about the geological structure can be obtained from the Geofond administered by the State Geological Institute of Dionýz Štúr. The Institute provides, through its website and WMS services, data from various areas such as Geology, Hydrogeology, Engineering Geology, Geophysics, Geochemistry, Soil, Mineral Resources, Mining Works and Geomorphological Division.

One of the serious issues that need to be addressed is environmental burdens and the reuse of brownfields by using the regional development management model [12].

In Slovakia, there are reserved deposits of energy raw materials, namely oil and Mineral oil, natural gas, Brown coal, lignite, uranium, anthracite and bituminous rocks. Anthracite and bituminous rock deposits are not mined, and their economic importance is marginal.

Figure 4 shows the course of the mining of energy raw materials. Mining increased moderately in 2013 and 2015, but since 2008 mining has been decreasing.

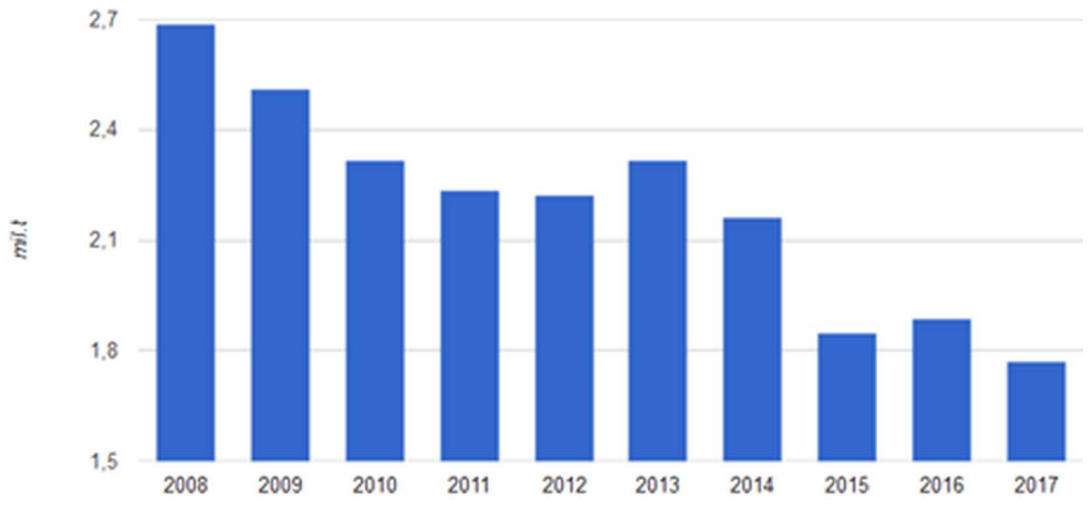

Fig. 4. Development of mining raw materials in Slovakia (Source: ŠGÚDŠ, processing by SAŽP).

Brown coal and lignite mining have decreased since $2242.82 \mathrm{kt}$ since 2008 to 1860.71 $\mathrm{kt}$ in 2017, which is related to the decline in coal mining in Slovakia.

Another important indicator is the energy intensity of the Slovak economy, which represents the structure of the economy expressed by combining economic and energy terms and thus expresses the degree of maturity of the country's economy - with regard to the efficiency of the use of primary energy sources, the specific consumption of materials and energy, the added value of the final product and so on. Reducing energy intensity in the economy is one of the objectives of an energy policy oriented towards environmental protection. 


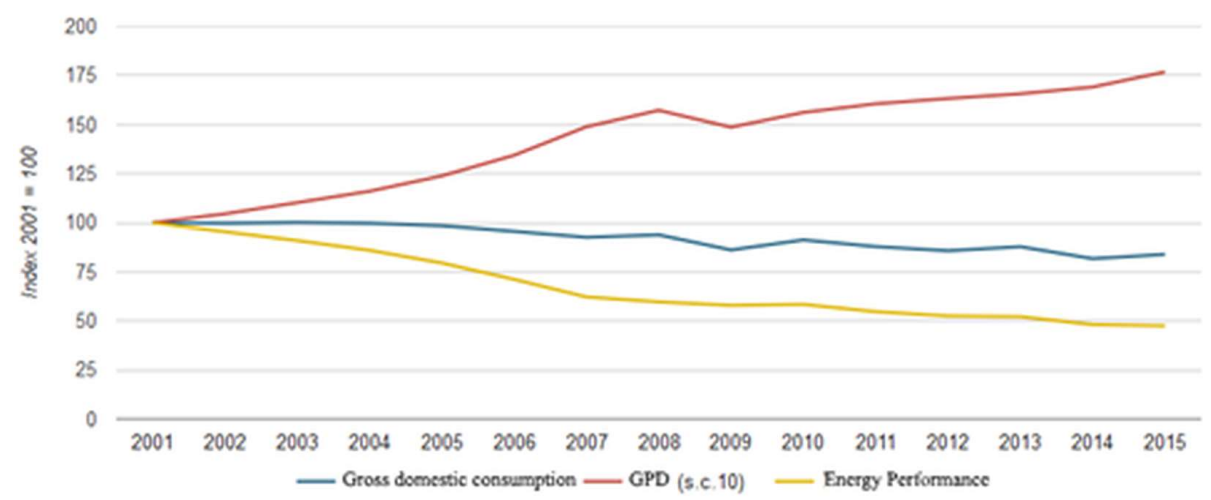

Fig. 5. Development of energy intensity compared to GDP and Energy performance (Source: ŠGÚDŠ, processing by SAŽP).

Figure 5 shows the indicator of the energy performance of the indicator compared to gross domestic consumption and gross domestic product. Since 2001 a decrease in the energy intensity of the whole economy has been achieved.

\section{Conclusion}

Protecting the environment increases our quality of life by saving and protecting fossil fuels and increasing the use of renewable energy sources. The development and development of society and the issue of measuring progress cannot only be identified with economic growth (GDP), but also the goals of not only the social sphere but also the environment must be met. The rate of the current use of non-renewable mineral resources must take into account their scarcity, non-renewability, technology level and availability of substitute resources. Possibilities of mining and consumption of non-renewable raw materials need to be regulated by real existing limits of the area and the environment. Excessive exploitation of mineral deposits, their treatment and processing result in significant interference with the natural environment. In order to solve problems related to sustainable development within its objective of rational use of natural resources, a comprehensive solution in cooperation with other experts within the interdisciplinary research is necessary.

\section{References}

1. Programové vyhlásenie vlády SR na roky 2016-2020 (Republic, Bratislava, 2016)

2. Aktualizácia surovinovej politiky SR pre oblast' nerastných surovín. URL: http://www.rokovania.sk/Rokovanie.aspx/BodRokovaniaDetail?idMaterial=10191

3. Energetická politika Slovenskej republiky. URL: http://www.rokovania.sk/Rokovanie.aspx/BodRokovaniaDetail?idMaterial=23993

4. P. Tauš, J. Koščo, R. Rybár, D. Kudelas, SGEM-2011, 320-25, 93-100 (2011)

5. Národná stratégia trvalo udržatel'ného rozvoja SR. URL: http://www.minzp.sk/dokumenty/strategicke-dokumenty/

6. Z. Šimková, M. Cehlár, H. Pavolová., Acta Montanistica Slovaca, 21:3, 208-216 (2016) 
7. Enviroportal, Indikátory TUR, Ukazovatele na hodnotenie plnenia Národnej stratégie trvalo udržatel'ného rozvoja $\mathrm{v}$ oblasti environmentálneho piliera TUR. URL: http://www1.enviroportal.sk/indikatory/schema.php?schema $=33$

8. S. Khouri, M. Cehlár, K. Horanský, K. Šándorová, Transformations in Business and Economics, 16:2B, 638-655 (2017)

9. Koncepcia energetickej efektívnosti SR. URL: http://www.rokovania.sk/Rokovanie.aspx/BodRokovaniaDetail?idMaterial=8637

10. J. Koščo, P. Tauš, M. Beer, R. Rybár, D. Kudelas, SGEM-2017, 13, 343-350 (2017)

11. Národný geoportal. URL: http://geoportal.gov.sk/

12. S. Khouri, H. Pavolová, M. Cehlár, T. Bakalár, Metalurgija, 55:3, 500-502 (2016) 